DOE/NV/26383-25

\title{
Timber Mountain Precipitation Monitoring Station
}

\author{
prepared by \\ Brad Lyles, Greg McCurdy, Jenny Chapman, and Julianne Miller
}

submitted to

Nevada Site Office

National Nuclear Security Administration

U.S. Department of Energy

Las Vegas, Nevada

January 2012

Publication No. 45239 
Reference herein to any specific commercial product, process, or service by trade name, trademark, manufacturer, or otherwise, does not necessarily constitute or imply its endorsement, recommendation, or favoring by the United States Government or any agency thereof or its contractors or subcontractors.

Available for sale to the public from:

U.S. Department of Commerce

National Technical Information Service

5301 Shawnee Road

Alexandria, VA 22312

Phone: 800.553 .6847

Fax: 703.605 .6900

Email: orders@ntis.gov

Online ordering: $\mathrm{http}: / / \mathrm{www}$.osti.gov/ordering.htm

Available electronically at http://www.osti.gov/bridge

Available for a processing fee to the U.S. Department of Energy and its contractors, in paper, from:

U.S. Department of Energy

Office of Scientific and Technical Information

P.O. Box 62

Oak Ridge, TN 37831-0062

Phone: 865.576 .8401

Fax: 865.576.5728

Email: reports@adonis.osti.gov 


\title{
Timber Mountain Precipitation Monitoring Station
}

\author{
prepared by \\ Brad Lyles, Greg McCurdy, Jenny Chapman, and Julianne Miller \\ Desert Research Institute \\ Nevada System of Higher Education
}

Publication No. 45239

submitted to

Nevada Site Office

National Nuclear Security Administration

U.S. Department of Energy

Las Vegas, Nevada

January 2012

The work upon which this report is based was supported by the U.S. Department of Energy under Contract \#s DE-AC52-06NA26383 and DE-NA0000939. Approved for public release; further dissemination unlimited. 
THIS PAGE INTENTIONALLY LEFT BLANK 


\section{CONTENTS}

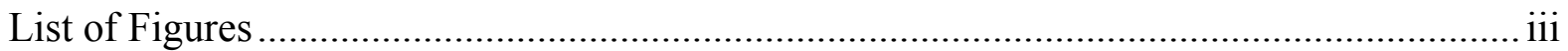

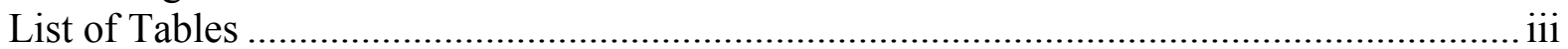

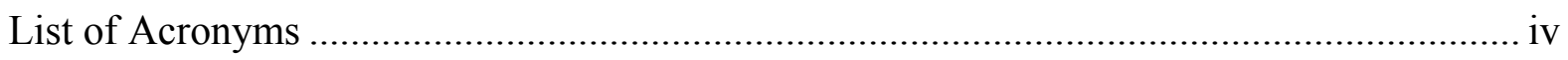

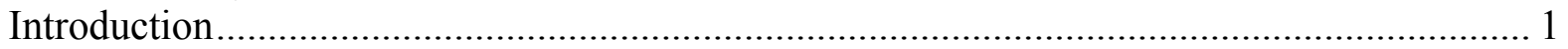

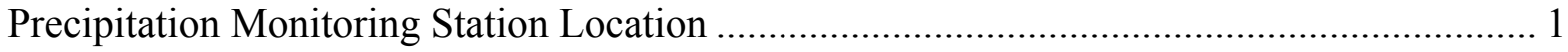

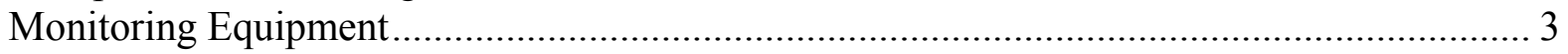

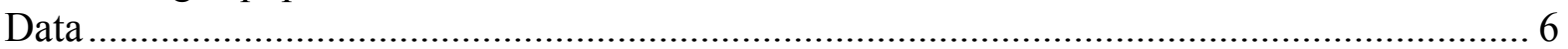

\section{LIST OF FIGURES}

1. Location of the Timber Mountain precipitation station relative to the NNSS and

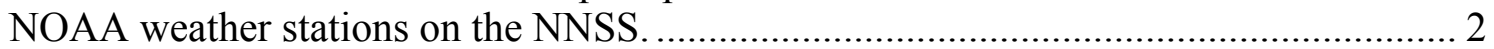

2. View looking southeast from the precipitation station, along the off-road vehicle track north of Cat Canyon Road. ................................................................................. 3

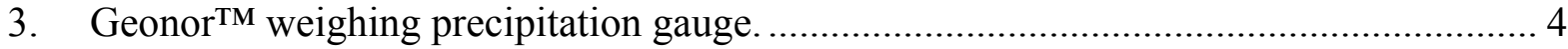

4. Schematic of equipment at the Timber Mountain precipitation station.......................... 4

5. The station site, looking southeast. ......................................................................... 5

6. View of the station, looking southwest............................................................. 5

7. Graphical summary of temperature, precipitation, and relative humidity data collected from the Timber Mountain precipitation station between July 1, 2010 until

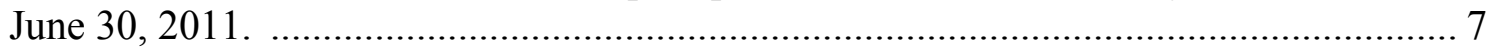

8. Graphical summary of wind and solar radiation data collected from the Timber Mountain precipitation station between July 1, 2011 until June 30, 2011_................... 8

9. Graphical representation of the annual wind rose patterns collected from the Timber Mountain precipitation station between July 1, 2011 until June 30, 2011.................... 8

10. Precipitation recorded at the NOAA network on the NNSS and at Timber Mountain

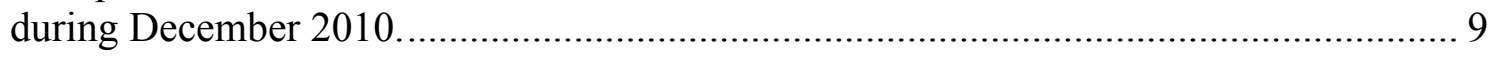

11. Timber Mountain - stable isotope plot of seasonal precipitation. .............................. 11

\section{LIST OF TABLES}

1. December 2010 monthly precipitation totals for stations not on the NNSS................ 10

2. Timber Mountain bulk precipitation chemical and stable isotopic analytical results..... 11 
CAU

DRI

EMSI

GOES

NAD

NOAA

NNSA/NSO

NNSS

NTTR

TDR

WRCC

\section{LIST OF ACRONYMS}

Corrective Action Unit

Desert Research Institute

Environmental Monitoring Systems Initiative

Geostationary Operational Environmental Satellite

North American Datum

National Oceanic and Atmospheric Administration

National Nuclear Security Administration, Nevada Site Office

National Nuclear Security Site

Nevada Test and Training Range

Time-Domain Reflectometry

Western Regional Climate Center 


\section{INTRODUCTION}

A precipitation monitoring station was placed on the west flank of Timber Mountain during the year 2010. It is located in an isolated highland area near the western border of the Nevada National Security Site (NNSS), south of Pahute Mesa. The cost of the equipment, permitting, and installation was provided by the Environmental Monitoring Systems Initiative (EMSI) project. Data collection, analysis, and maintenance of the station during fiscal year 2011 was funded by the U.S. Department of Energy, National Nuclear Security Administration, Nevada Site Office Environmental Restoration, Soils Activity.

The station is located near the western headwaters of Forty Mile Wash on the Nevada Test and Training Range (NTTR). Overland flows from precipitation events that occur in the Timber Mountain high elevation area cross several of the contaminated Soils project CAU (Corrective Action Unit) sites located in the Forty Mile Wash watershed. Rain-on-snow events in the early winter and spring around Timber Mountain have contributed to several significant flow events in Forty Mile Wash. The data from the new precipitation gauge at Timber Mountain will provide important information for determining runoff response to precipitation events in this area of the NNSS. Timber Mountain is also a groundwater recharge area, and estimation of recharge from precipitation was important for the EMSI project in determining groundwater flowpaths and designing effective groundwater monitoring for Yucca Mountain. Recharge estimation additionally provides benefit to the Underground Test Area Sub-project analysis of groundwater flow direction and velocity from nuclear test areas on Pahute Mesa. Additionally, this site provides data that has been used during wild fire events and provided a singular monitoring location of the extreme precipitation events during December 2010 (see data section for more details).

This letter report provides a summary of the site location, equipment, and data collected in fiscal year 2011.

\section{PRECIPITATION MONITORING STATION LOCATION}

The monitoring location is at N $37^{\circ} 03^{\prime} 33^{\prime \prime}$ and W $116^{\circ} 27^{\prime} 52^{\prime \prime}$ (NAD 27) at an elevation of $6,500 \mathrm{ft}$. The site is on the NTTR about 1 mile west of the NNSS/NTTR boundary and about 0.25 mile north of the Cat Canyon Road (Figure 1). This road, which goes west to US 95 just north of Beatty, is used for access. The station is located on a previously disturbed area that houses a seismic monitoring station operated by the University of Nevada at Reno. Cultural resources surveys were conducted in the mid-1990s when the seismic station was installed, including a corridor from the road to the station that remains as a rough off-road vehicle track. The total footprint for the weather station is an area of about 20 by 25 feet, although most of this is for the guy-wires associated with the tower.

Access to the site along the Cat Canyon road is coordinated with NTTR. A Range Visit Request/Authorization form must be approved for each site worker weeks before each trip. The Tolicha Peak security station coordinates entry and exit from the range. Exact procedures for site access, including contact information and numbers, are detailed in the Work Control Package.

Topographically, the site is located on a south-facing slope of a bowl that opens to the west. It is in a mixed Juniper-sagebrush-ephedra community with occasional piñon pine trees (Figure 2). 


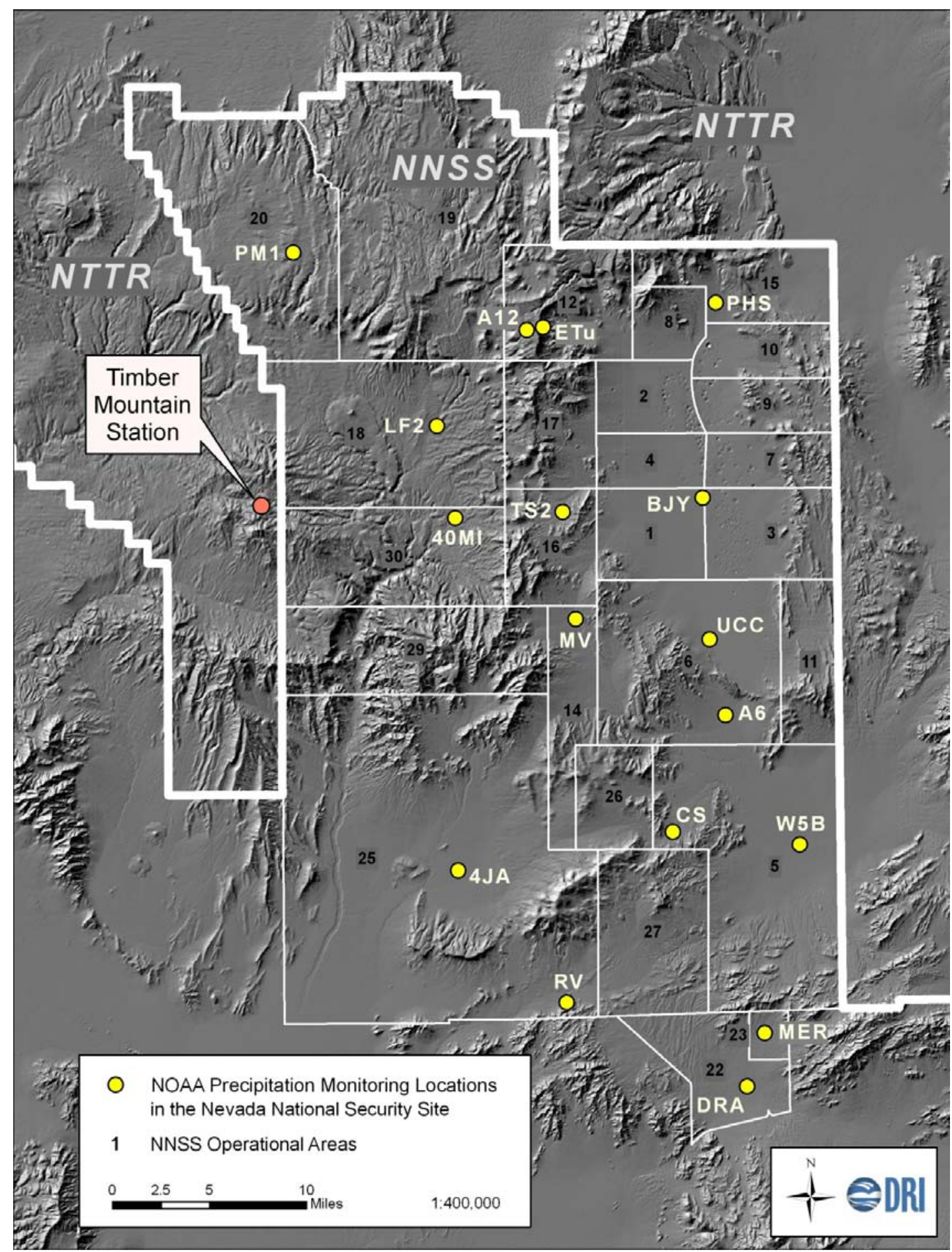

Figure 1. Location of the Timber Mountain precipitation station relative to the NNSS and NOAA weather stations on the NNSS. 


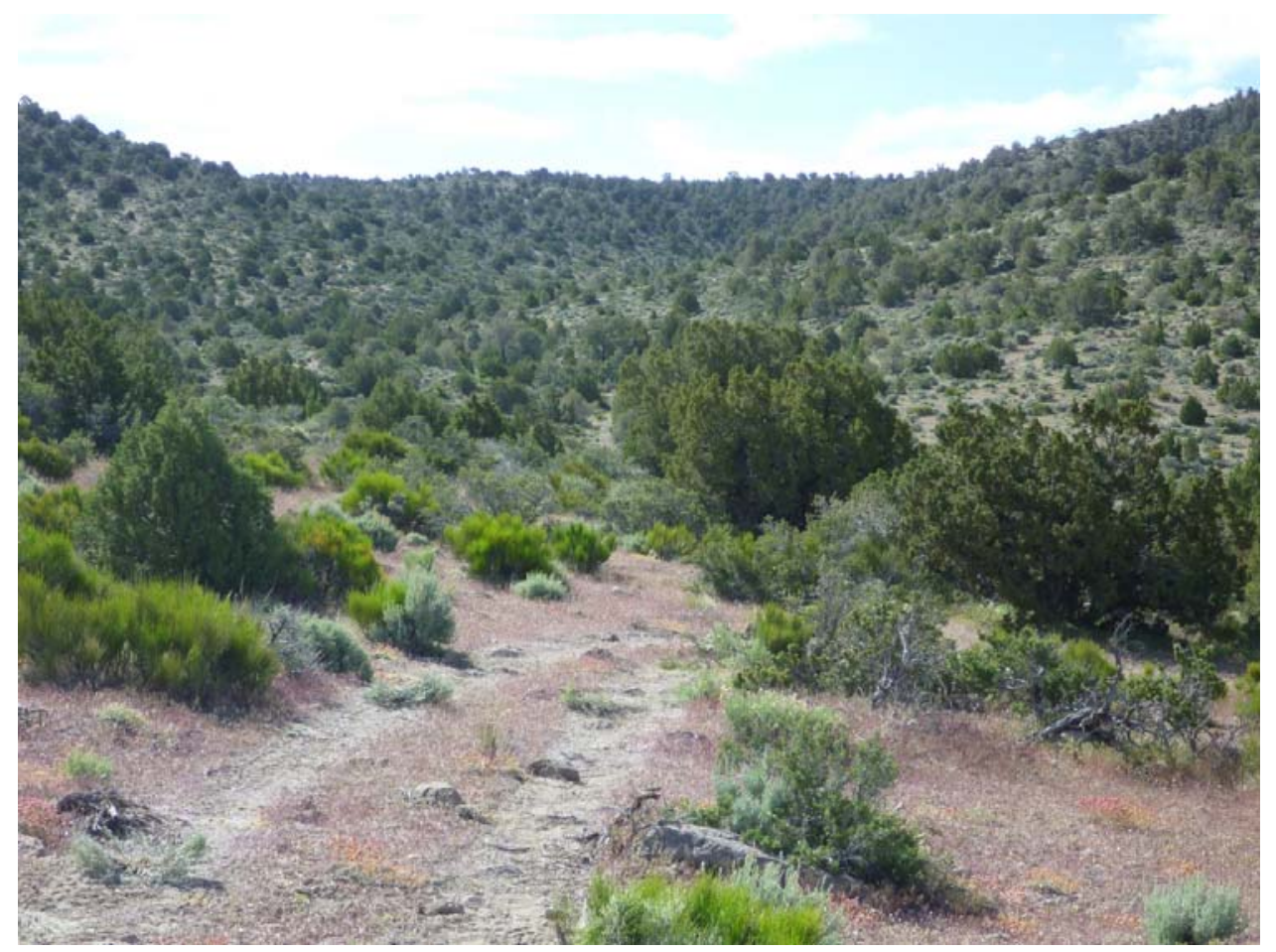

Figure 2. View looking southeast from the precipitation station, along the off-road vehicle track north of Cat Canyon Road.

\section{MONITORING EQUIPMENT}

The primary equipment for precipitation monitoring is a weighing-type Geonor ${ }^{\mathrm{TM}}$ Gauge (Figure 3). It is used to measure the timing, intensity, and duration of rainfall and snowfall events. A secondary, tipping-bucket, precipitation gauge is also installed (Hydrologic Services ${ }^{\mathrm{TM}}$ model TB-4). These two precipitation gauges are the standard equipment installed for the Climate Reference Network operated by the National Oceanic and Atmospheric Administration (NOAA). Soil moisture is monitored with Time-Domain Reflectometry (TDR) probes at depths of 2, 4, and 8 inches to track infiltration of precipitation. The station tower includes sensors for wind direction, wind speed, air temperature, relative humidity, solar radiation, and snow depth (Figure 4). Soil temperature is measured via thermocouples embedded at the same depths as the TDR probes. Figures 5 and 6 are photographs of the installed site.

The weather sensors are automatically sampled every three seconds, and the soil sensors are sampled each minute by a Campbell Scientific ${ }^{\mathrm{TM}}$ data logger. These data streams are then summarized and stored for 10-minute and 60-minute periods. The 60-minute data are transmitted by Geostationary Operational Environmental Satellite (GOES) to the DRI Western Regional Climate Center (WRCC), where a database for the station is maintained. The 10-minute data are retrieved during servicing trips to the station. 

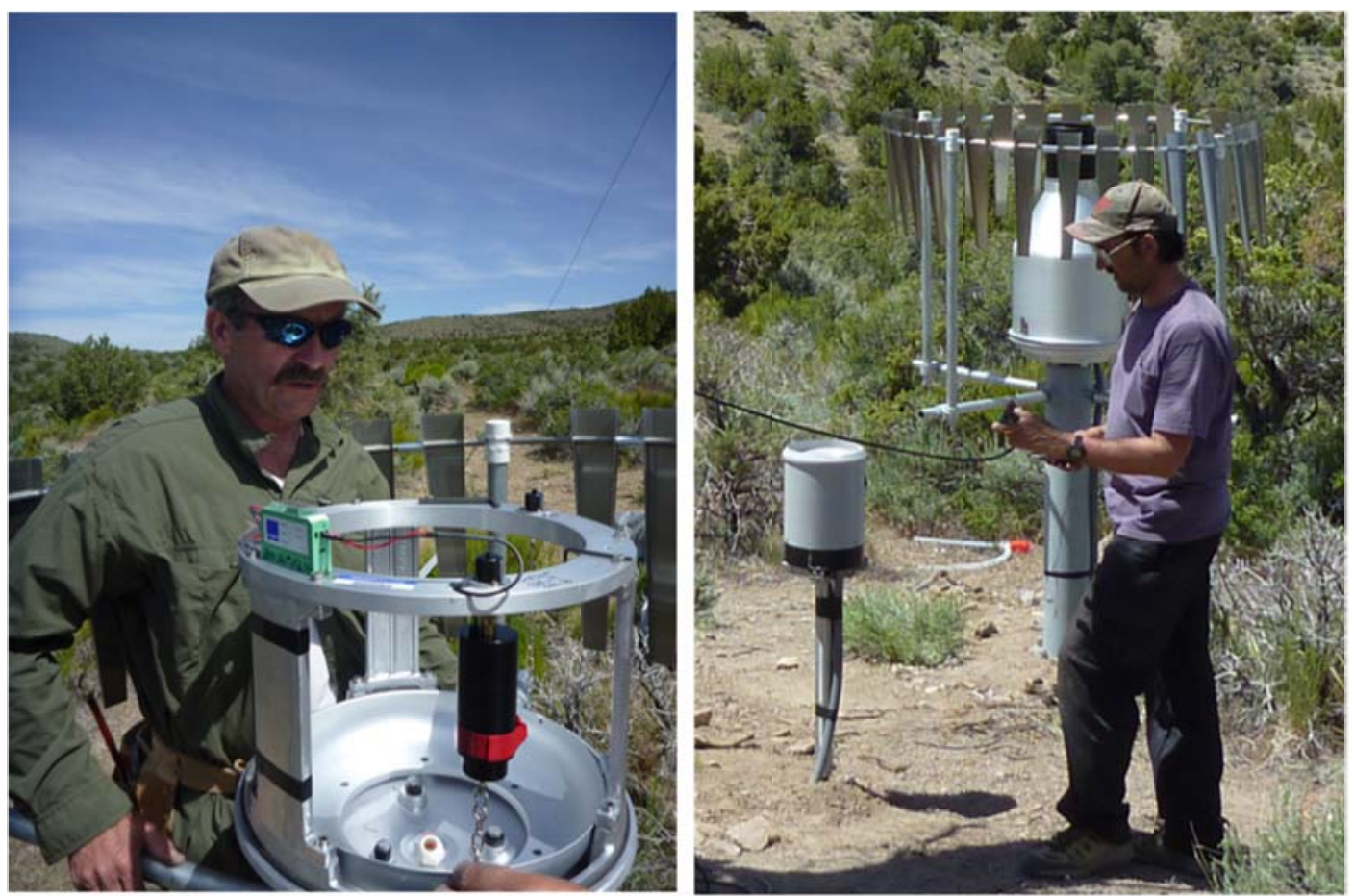

Figure 3. Geonor ${ }^{\mathrm{TM}}$ weighing precipitation gauge. The outer cover is removed in the left photo, with a view of the completed installation on the right. The secondary, tipping-bucket type, gauge can be seen to the left of the Geonor gauge.

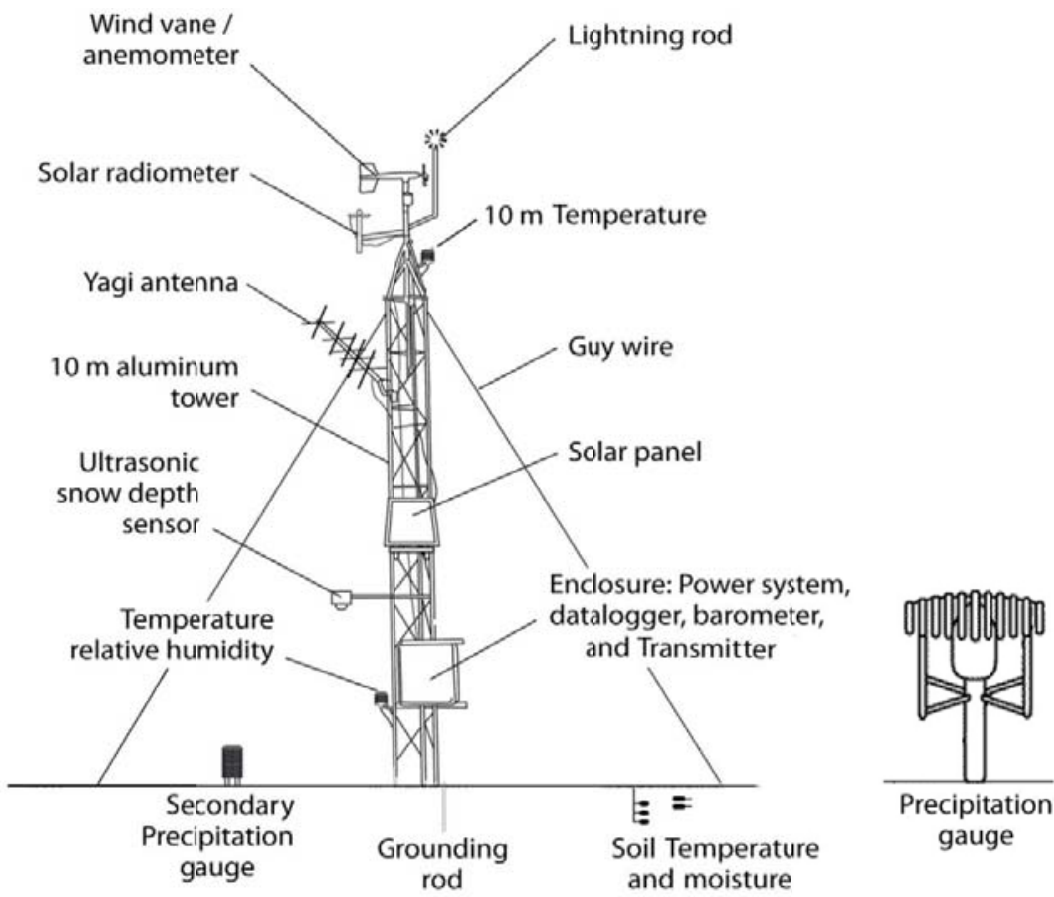

Figure 4. Schematic of equipment at the Timber Mountain precipitation station. 


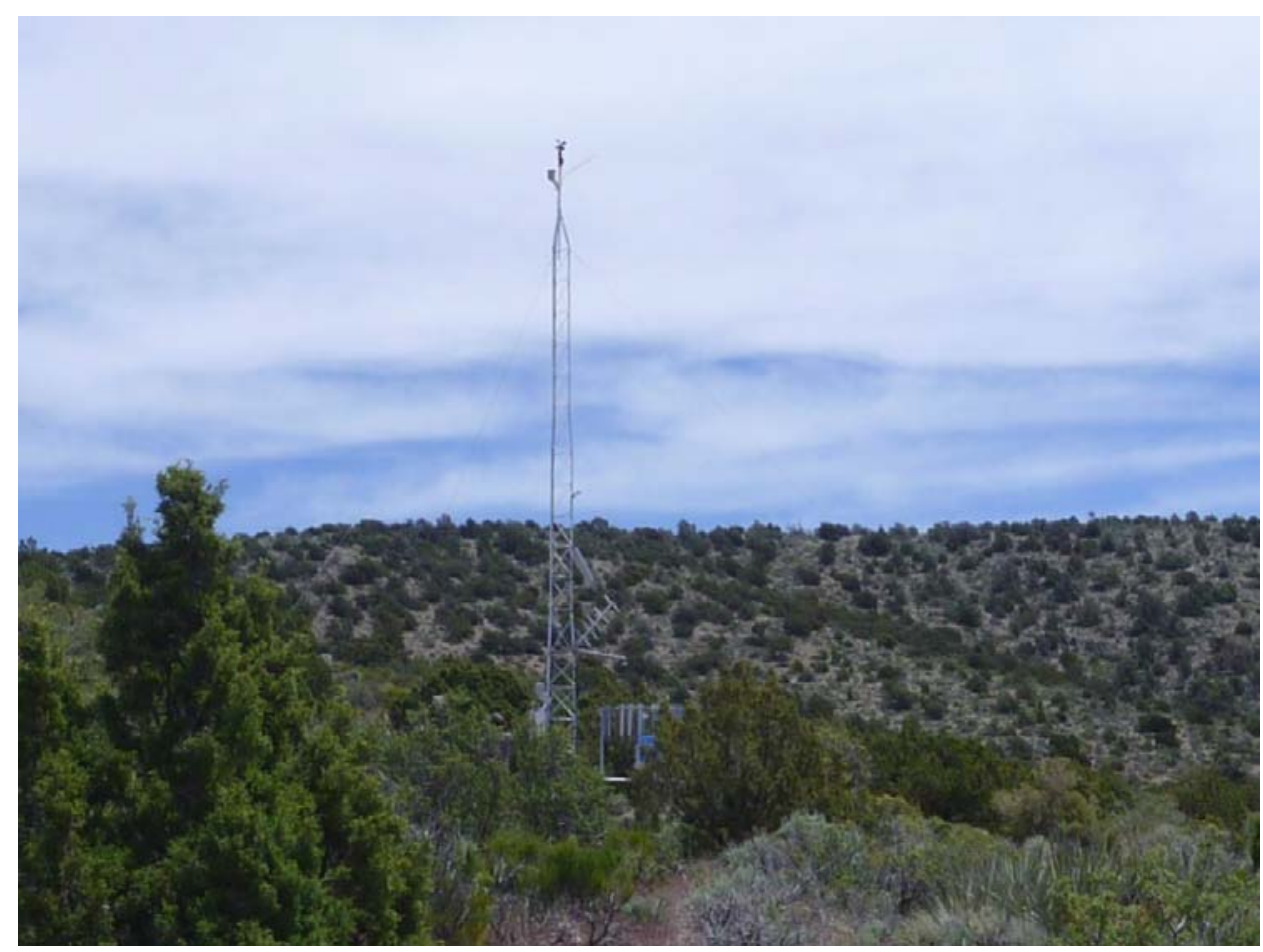

Figure 5. The station site, looking southeast. The Geonor gauge can be seen to the right of the tower.

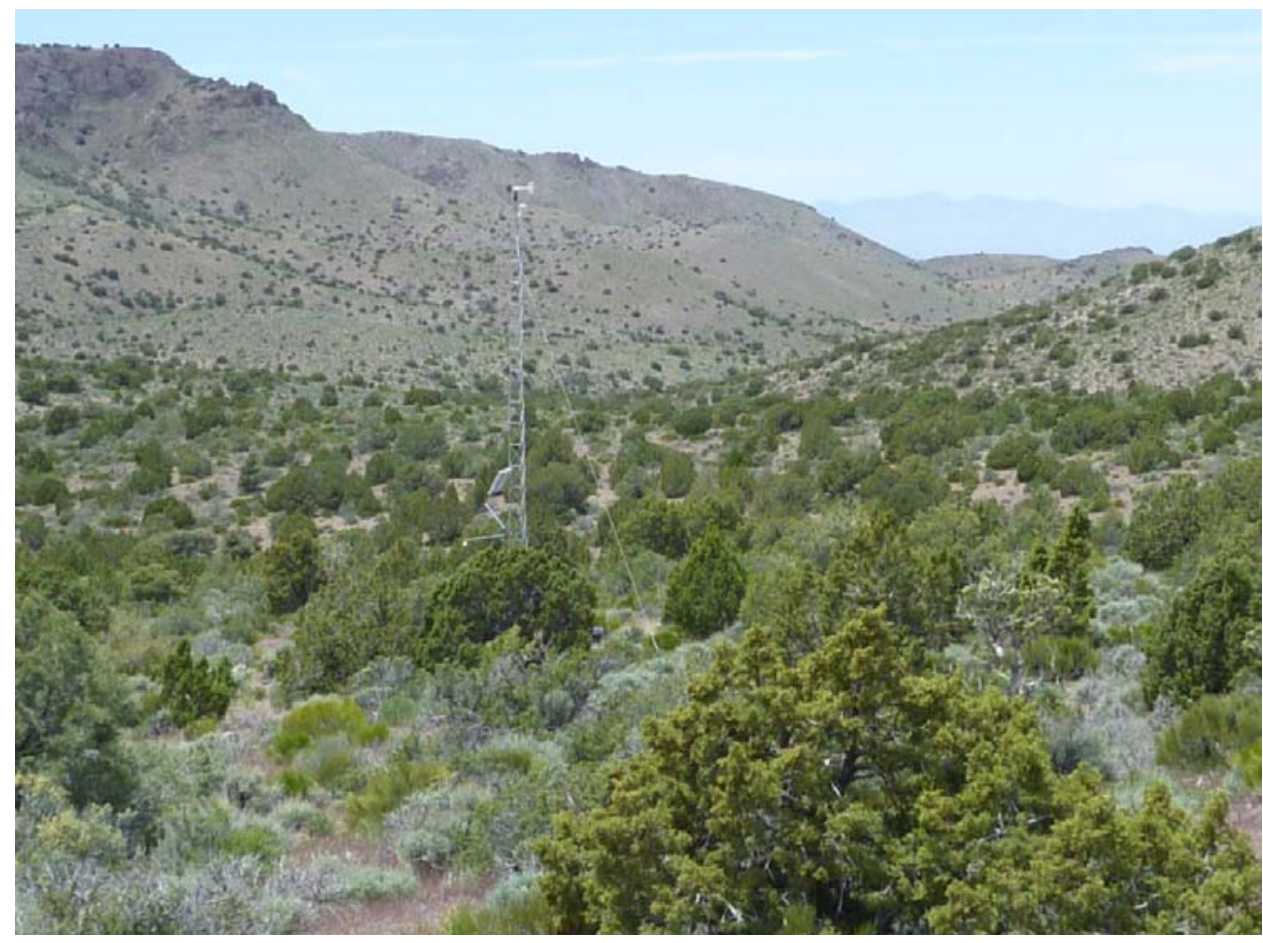

Figure 6. View of the station, looking southwest. 
A bulk precipitation gauge is used to accumulate an integrated sample of rain and snow. The gauge is pre-charged with mineral oil to reduce evaporation and preclude isotopic exchange with the atmosphere. During site visits, water samples are collected to measure chloride concentration, and for analysis of stable isotopic ratios of oxygen and hydrogen. The chloride provides an initial concentration for comparing precipitation with soil water and runoff water. The stable isotopes similarly provide a means of tagging the precipitation for comparison to downstream samples, and additionally can be used to interpret the source of precipitation (e.g., frontal systems from the northern Pacific versus monsoonal moisture).

\section{DATA}

Data from the Timber Mountain station are transmitted, stored and managed at the WRCC in Reno, Nevada. Data began transmitting from the site at 11 am on June 4, 2010. At the end of the 2011 federal fiscal year on September 30, 2011, 484 days of data have been collected. Available data include:

- Solar radiation

- Wind speed (average and maximum) and direction

- Ambient air temperature (minimum, maximum, and average)

- Soil temperature @ 4" depth (minimum, maximum, and average)

- Relative humidity (minimum, maximum, and average)

- Dew point and wet bulb temperature

- Barometric pressure

- Snow depth

- Precipitation

For the July 1, 2010 to June 30, 2011 time period, 11.01 inches of precipitation were measured, with 4.12 inches falling during a 1-week period in December 2010. The highest recorded temperature at the site was $94^{\circ} \mathrm{F}$ (July 15, 2010) and the lowest was $9^{\circ} \mathrm{F}$ (December 31, 2010). The maximum wind gust was 51mph (May 15, 2011), with the predominant wind direction for the year from the southeast. Graphical representation of the data record is presented in Figures 7 and 8. Figure 9 shows the annual wind rose for the same period. As depicted in the wind rose, the winds are most frequently blowing from the southeast. These are usually due to local drainage winds and are typically light $(<8 \mathrm{mph})$, although the highest frequency of moderate winds (8-13 MPH) are also from the southeast. The stronger winds are usually from the south, southwest or northwest and are associated with orographic winter storms or convective summer storms. Current weather data can be accessed via the internet at http://www.wrcc.dri.edu/weather/index.html, with Timber Mountain listed in the Nevada grouping.

Two events of particular note occurred during the past year. First was the unusual winter storm in December 2010. The station recorded 14 days of recordable precipitation with eight days of consecutive precipitation from the $16^{\text {th }}$ to the $23^{\text {rd }}$. The 5.19 " monthly total at the site was comparable to some of the amounts recorded on the NNSS through the NOAA network (Figure 10), but over twice the amount at other sites, particularly off-NNSS locations to the west and southwest (Table 1). The weather pattern for the week created a steady plume of moisture on a relatively narrow corridor across southern Nevada. Timber Mountain appears to have been on the western edge of this plume with December $20^{\text {th }}$ and December $22^{\text {nd }}$ receiving more than 1 " each day. The information from Timber Mountain 
provided important data for the area between Beatty and the western area of the NNSS where no other observations are available.

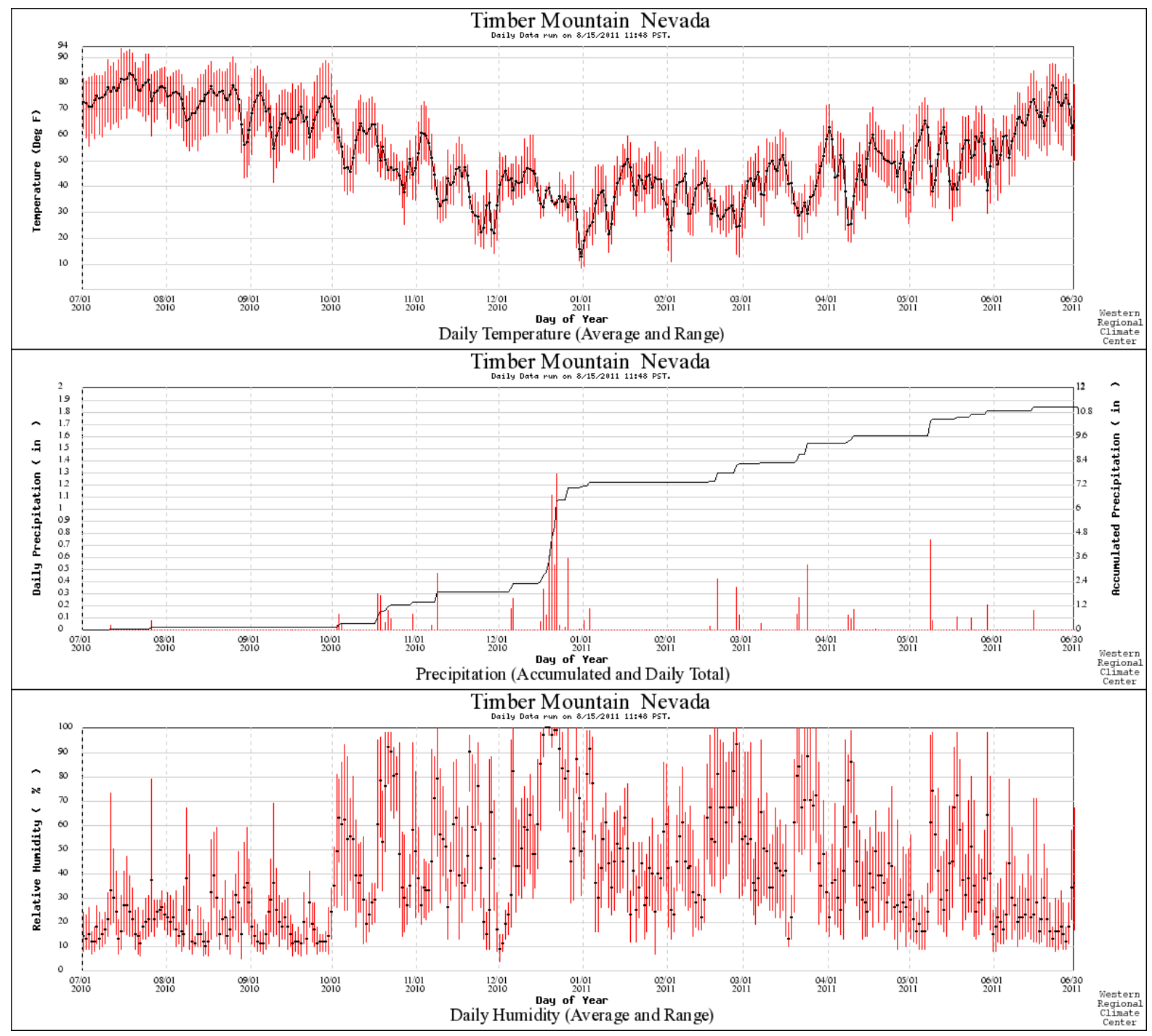

Figure 7. Graphical summary of temperature, precipitation, and relative humidity data collected from the Timber Mountain precipitation station between July 1, 2010 until June 30, 2011. Copyright: Western Regional Climate Center - Desert Research Institute - Reno, Nevada. Data are subject to further review and editing. 


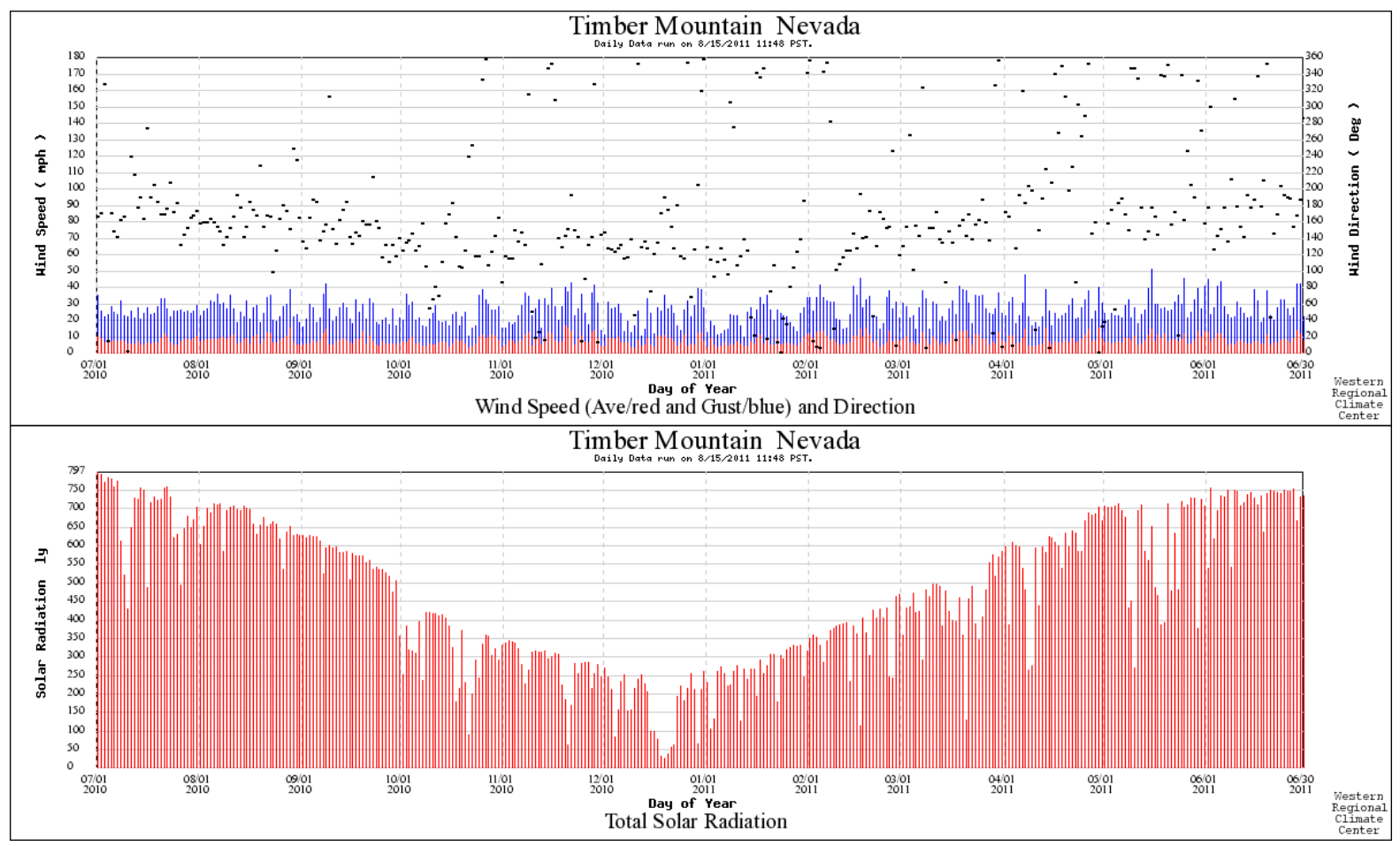

Figure 8. Graphical summary of wind and solar radiation data collected from the Timber Mountain precipitation station between July 1, 2011 until June 30, 2011. Copyright: Western Regional Climate Center - Desert Research Institute - Reno, Nevada. Data are subject to further review and editing.

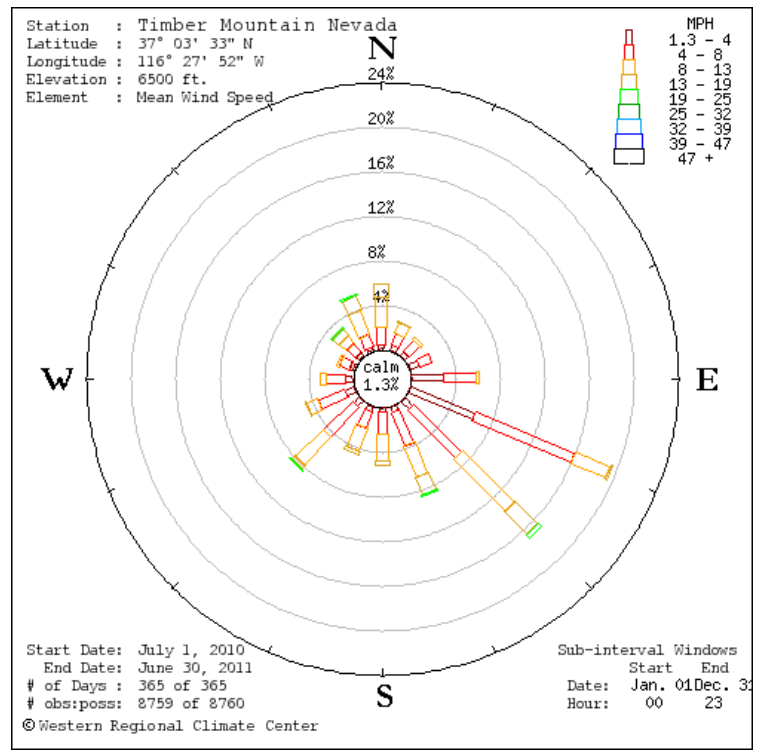

Figure 9. Graphical representation of the annual wind rose patterns collected from the Timber Mountain precipitation station between July 1, 2011 until June 30, 2011. Copyright: Western Regional Climate Center - Desert Research Institute - Reno, Nevada. Data are subject to further review and editing. 


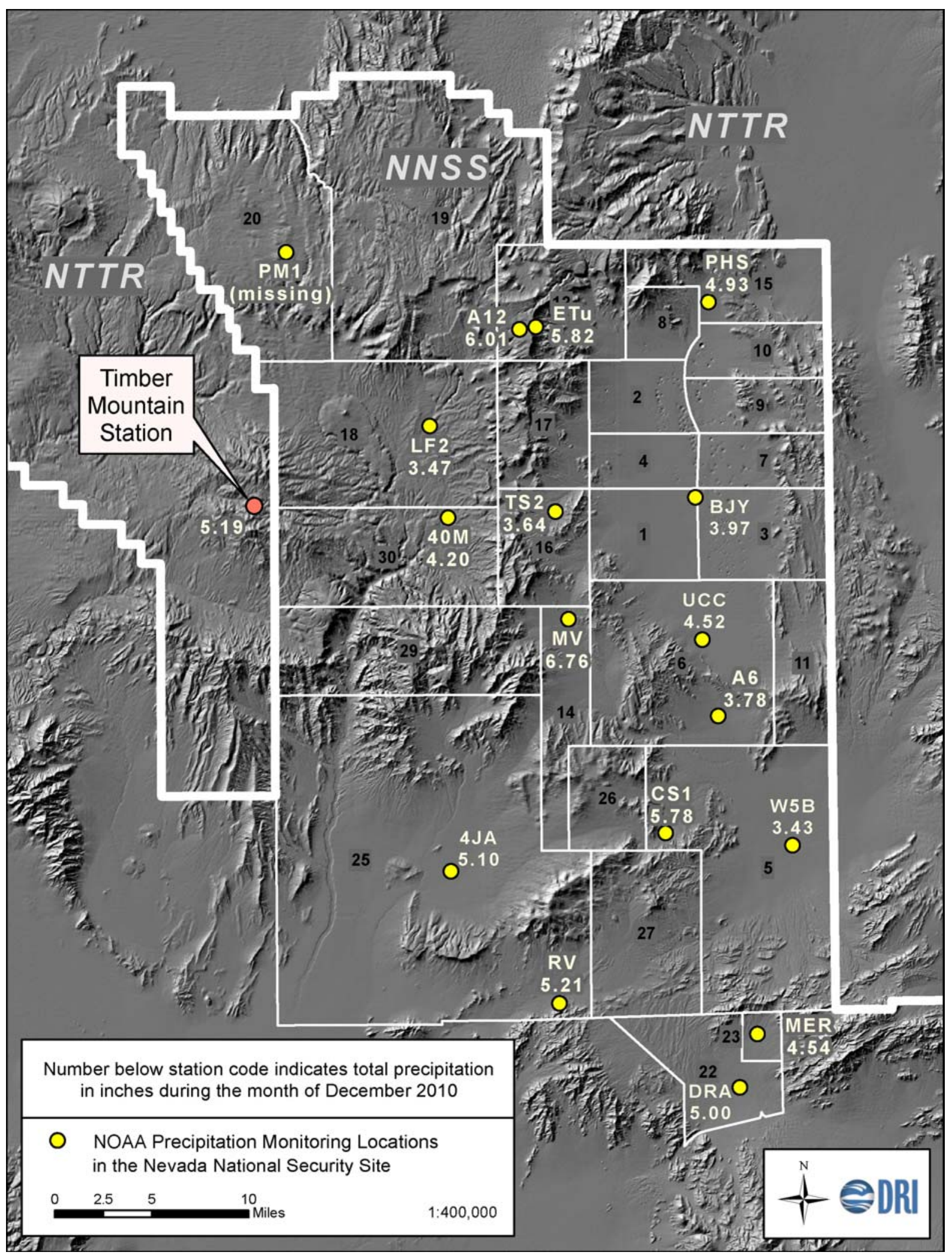

Figure 10. Precipitation recorded at the NOAA network on the NNSS and at Timber Mountain during December 2010. 
Table 1. December 2010 monthly precipitation totals for stations not on the NNSS.

\begin{tabular}{lc}
\hline \multicolumn{1}{c}{ Station } & $\begin{array}{c}\text { December 2010 Precipitation } \\
\text { (inches) }\end{array}$ \\
\hline Timber Mountain & 5.19 \\
Beatty - CEMP & 1.64 \\
Buddy Adams - BLM RAWS 3mi W of Timber Mountain & 2.05 \\
Amargosa Valley - CEMP & 2.09 \\
Rogers Spring - Ash Meadows NWR & 2.71 \\
Indian Springs - CEMP & 2.21 \\
Corn Creek - Yucca Gap RAWS & 1.94 \\
Desert Wildlife Refuge - Twin Buttes RAWS & 2.76 \\
Pahranagat Wildlife Refuge & 3.04 \\
Kyle Canyon RAWS & 14.06 \\
Red Rock RAWS (W Las Vegas) & 5.56 \\
Garden Spring (Tule Desert, north of Mesquite) & 11.46 \\
Kane Springs & 5.51 \\
Alamo - CEMP & 3.29 \\
Mesquite - CEMP & 3.19 \\
Pine Nut - SNOTEL (Desert Wildlife Refuge) & 7.58 \\
\hline
\end{tabular}

The second event of note was the wildfire outbreak on Timber Mountain during July 2011. The Timber Mountain weather station provided the only real-time weather observations for use to the fire fighters and personnel working around Timber Mountain. Information was provided to dispatch and other monitoring personnel.

The data collected during both of these events demonstrates the importance of the Timber Mountain weather station and the spatial data gap it is filling. The station is providing benchmark precipitation data where none existed previously, data that are invaluable for assessing groundwater resources and surface runoff; UGTA and Soil Activities can use this data in future modeling efforts to estimate mountain block recharge. The precipitation record at the station confirms that Timber Mountain is an important recharge area for the NNSS. With the increased frequency of fires, the ability to provide wind and temperature data within the area also proved to be a valuable emergency response resource.

A bulk precipitation gauge was installed December 1, 2010, consisting of an 8-inch diameter stainless steel tank, wind alter shield, and mineral oil to preclude evaporation. Water samples collected from the bulk precipitation gage were analyzed for major cations/anions and stable isotopes, and may be used to identify the chemical and isotopic signature of mountain block recharge water (see Table 2). The sample collected in May is representative of the average wet/dry fall during the winter (December to May), likewise the sample collected in September is the average from the summer (May to September); only subtle differences were observed, most notably chloride was 2.5 times and potassium was 6 times great during the summer. Stable isotopes plotted on the global meteoric water line, as 
shown on Figure 11; winter precipitation was isotopically lighter than summer precipitation, as expected.

Table 2. Timber Mountain bulk precipitation volume, chemical and stable isotopic analytical results.

\begin{tabular}{|c|c|c|c|}
\hline & units & $\begin{array}{c}\text { 16-May-11 } \\
\text { winter }\end{array}$ & $\begin{array}{c}\text { 20-Sep-11 } \\
\text { summer }\end{array}$ \\
\hline pH & & 7.53 & 6.65 \\
\hline EC & $\mathrm{uS} / \mathrm{cm}$ & 80 & 87 \\
\hline $\mathrm{SiO}_{2}$ & $\mathrm{mg} / 1$ & 0.6 & 1.9 \\
\hline $\mathrm{HCO}_{3}$ & $\mathrm{mg} / \mathrm{l}$ & 40.8 & 38.8 \\
\hline $\mathrm{CO}_{3}$ & $\mathrm{mg} / 1$ & $<.1$ & $<.1$ \\
\hline Cl & $\mathrm{mg} / 1$ & 0.99 & 2.37 \\
\hline $\mathrm{SO}_{4}$ & $\mathrm{mg} / \mathrm{l}$ & 3.46 & 3.21 \\
\hline $\mathrm{NO}_{3}-\mathrm{N}$ & $\mathrm{mg} / \mathrm{l}$ & 0.011 & 0.011 \\
\hline $\mathbf{N a}$ & $\mathrm{mg} / \mathrm{l}$ & 1.34 & 1.36 \\
\hline K & $\mathrm{mg} / \mathrm{l}$ & 0.42 & 2.60 \\
\hline $\mathbf{C a}$ & $\mathrm{mg} / \mathrm{l}$ & 12.6 & 10.7 \\
\hline Mg & $\mathrm{mg} / \mathrm{l}$ & 0.95 & 1.06 \\
\hline $\mathbf{F}$ & $\mathrm{mg} / \mathrm{l}$ & 0.17 & 0.11 \\
\hline $\mathrm{Br}$ & $\mathrm{mg} / 1$ & $<.01$ & 0.01 \\
\hline$\delta^{18} O$ & per mil & -16.6 & -9.7 \\
\hline$\delta \mathbf{D}$ & per mil & -122 & -68 \\
\hline Cumulative Precipitation & inches & 8.875 & 2.125 \\
\hline
\end{tabular}

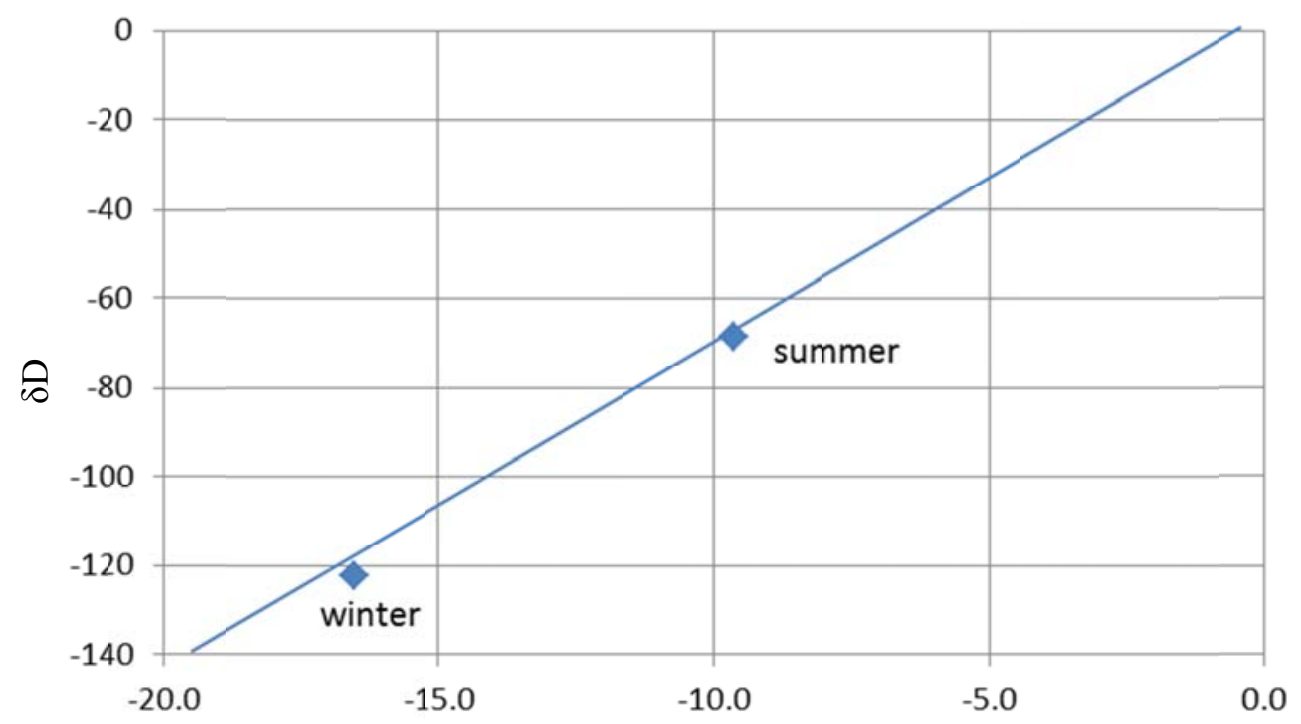

Figure 11. Timber Mountain - stable isotope plot of seasonal precipitation. The data plot on the SMOW (Standard Mean Ocean Water) meteoric water line $\delta \mathrm{D}=8 \delta^{18} \mathrm{O}+10$, and as expected, winter precipitation is isotopically lighter than summer precipitation. 